\title{
PENGEMBANGAN INSTRUMEN PENILAIAN TES BERBASIS MOBILE ONLINE PADA PRODI PENDIDIKAN MATEMATIKA
}

\author{
${ }^{1}$ Rachmawati, ${ }^{2}$ Anik Kurniawati \\ ${ }^{1,2}$ IKIP Budi Utomo Malang, Jalan Citandui 46, Malang, Jawa Timur, Indonesia \\ e-mail: rachmawati603@gmail.com
}

\begin{abstract}
Abstrak
Penelitian ini dilakukan untuk memberikan inovasi evaluasi hasil tes yang bebas kertas, yaitu dengan evaluasi berbasis mobile online yang menggunakan Google Form. Evaluasi berbasis mobile online merupakan evaluasi yang menggunakan perangkat elektronik mobile(ponsel). Penelitian pengembangan ini menggunakan model pengembangan 4D (define, design, develop, dan disseminate). Tahap disseminate tidak dilaksanakan dalam penelitian karena produk hanya terbatas penggunaannya pada mahasiswa program studi Pendidikan Matematika IKIP Budi Utomo Malang pada mata kuliah Belajar dan Pembelajaran. Instrumen penelitian ini adalah lembar validasi ahli, soal tes dan angket respon mahasiswa. Instrumen penilaian tes berbasis mobile online berbantuan Google Form yang dikembangkan memenuhi aspek kevalidan, kepraktisan, dan keefektifan. Penilaian aspek kevalidan berdasarkan lembar validasi ahli media berada pada kriteria valid rata-rata 3,66. Penilaian aspek kepraktisan berdasarkan angket respon user (mahasiswa) berada pada kriteria baik dengan rata-rata 3,02. Penilaian asspek keefektifan berdasarkan hasil tes mahasiswa berada pada kriteria baik dengan rata-rata 80,67. Jadi instrumen penilaian tes mobile online berbantuan Google Form yang dikembangkan layak digunakan untuk evaluasi pembelajaran.
\end{abstract}

Kata Kunci: instrumen evaluasi, mobile online, Google form, pendidikan matematika, belajar dan pembelajaran

\begin{abstract}
This research was conducted to provide paper-free evaluation of test results innovations, namely with online mobile-based evaluations that use Google Form. Mobile online based evaluation is an evaluation that uses mobile electronic devices (cellphones). This development research uses a 4D development model (define, design, develop, and disseminate). The disseminate stage was not carried out in the study because the product was only limited in its use to the students of the Mathematics Education Program at IKIP Budi Utomo Malang on the subject of Learning and Learning. The instruments of this study were expert validation sheets, test questions and student response questionnaires. The Google Form-based mobile online-based test assessment instrument developed meets aspects of validity, practicality and effectiveness. Evaluation of validity aspects based on the validation sheet of media experts is on valid criteria on average 3.66. The assessment of practical aspects based on the response questionnaire of users (students) is in good criteria with an average of 3.02. The assessment of effectiveness aspects based on student test results is in good criteria with an average of 80.67. So the Google Form assisted online mobile test assessment instrument that is developed is appropriate for evaluation of learning.
\end{abstract}

Keywords: evaluation instruments, mobile online, Google form, Mathematic Education, Belajar dan Pembelajaran

\section{PENDAHULUAN}

Belajar dan Pembelajaran merupakan salah satu mata kuliah institusi yang wajib ditempuh mahasiswa Pendidikan Matematika IKIP Budi Utomo Malang. Standar kompetensi dalam mata kuliah ini adalah agar mahasiswa dapat menerapkan konsep dasar belajar pembelajaran. Pengertian belajar menurut Abdillah dalam Aunurrahman (2014) adalah suatu proses yang dilakukan individu untuk memperoleh sesuatu perubahan tingkah laku yang baru secara keseluruhan, sebagai hasil pengalaman individu itu sendiri di dalam interaksi dengan 
lingkungannya. Sejumlah pandangan dan definisi tentang belajar menurut Wragg (1994), kita menemukan beberapa ciri umum kegiatan belajar sebagai berikut: 1. Belajar menunjukkan suatu aktivitas pada diri seseorang yang disadari atau disengaja, 2. Belajar merupakan interaksi individu dengan lingkungannya, dan 3. Belajar ditandai dengan perubahan tingkah laku. Sehingga dapat kita simpulkan belajar adalah suatu usaha sadar yang dilakukan oleh individu dalam perubahan tingkah laku baik melalui latihan dan pengalaman yang menyangkut aspekaspek kognitif, afektif, dan psikomotor untuk memperoleh tujuan tertentu.

Adapun manfaat mata kuliah Belajar dan Pembelajaran di antaranya 1) Mahasiswa dapat memahami konsep dasar dalam belajar dan pembelajaran. 2) Mahasiswa mampu menerapkan konsep dasar belajar dan pembelajaran di sekolah. Mata kuliah ini meliputi kajian hakikat belajar dan pembelajaran, prinsip dan implikasi belajar pembelajaran, teori belajar dan implementasi dalam proses pembelajaran, gaya dan masalah-masalah belajar, siklus belajar, komunikasi pembelajaran, metode pembelajaran inovatif, dan evaluasi pembelajaran.

Disebutkan dalam Permendiknas Nomor 20 Tahun 2007 tentang Standar Penilaian Pendidikan adalah proses pengumpulan dan pengolahan informasi untuk menentukan pencapaian hasil belajar peserta didik. Prinsip dan standar dalam penilaian menekankan pada dua ide pokok yaitu penilaian harus meningkatkan belajar peserta didik dan penilaian merupakan sebuah alat untuk membuat keputusan pengajaran. Penilaian tidak sekedar pengumpulan data peserta didik, tetapi juga pengolahannya untuk memperoleh gambaran proses dan hasil belajar peserta didik yang telah dilakukan. Penilaian tidak sekedar memberi soal peserta didik kemudian selesai, tetapi pendidik juga harus menindaklanjutinya untuk kepentingan pembelajaran. Untuk melaksanakan proses pembelajaran yang baik penilaian juga harus dilakukan untuk mengetahui perkembangan kemampuan peserta didik (Budiman \& Jailani, 2014).

Pelaksanaan pembelajaran mata kuliah Belajar dan Pembelajaran didalamnya terdapat evaluasi. Evaluasi merupakan bagian dari proses belajar mengajar yang secara keseluruhan kegiatannya tidak dapat dipisahkan dari kegiatan mengajar. Dalam Sukardi (2012)aturan yang terkait dengan hal tersebut tercantun dalam UUR No. 20 Tahun 2003 Pasal 58 Ayat (1) tentang Sisdiknas, yang menyatakan bahwa evaluasi hasil belajar peserta didik dilakukan oleh pendidik untuk memantau proses, kemajuan, dan perbaikan hasil belajar peserta didik secara berkesinambungan.

Definisi yang pertama dikembangkan oleh Ralph Tyler dalam Arikunto (2012) mengatakan bahwa evaluasi merupakan suatu proses pengumpulan data untuk menentukan 
sejauh mana, dalam hal apa, dan bagaimanatujuan pendidikan sudah tercapai. Definisi yang lebih luas dikemukakan oleh dua orang ahli lain, yakni Cronbach dan Stufflebean adalah bahwa proses evaluasi bukan sekedar mengukur sejauh mana tujuan tercapai, tetapi juga digunakan untuk membuat keputusan-keputusan. Evaluasi dapat berupa tugas setelah kegiatan belajar mengajar, UTS (Ujian Tengah Semester), dan UAS (Ujian Akhir Semester).

Instrumen dalam evaluasi pembelajaran menurut Zamzania dan Aristia (2018) dibedakan menjadi 2, yaitu: 1 . Tes objektif adalah tes tertulis yang menuntut siswa untuk memilih jawaban yang telah disediakan atau memberikan jawaban singkat dan pemeriksaannya dilakukan secara objektif (seragam) terhadap semua peserta tes. Ada beberapa jenis tes dalam bentuk objektif yaitu: pilihan ganda, bentuk pilihan benar salah, menjodohkan, dan isian singkat. 2. Tes non objektif atau disebut tes uraian yaitu tes yang isi pertanyannya membutuhkan jawaban peserta tes untuk menguraikan, mengorganisasikan dan menyatakan jawaban dengan kata-katanya sendiri dalam bentuk, teknik, dan gaya yang berbeda satu dengan yang lainnya. Bentuk uraian sering juga disebut bentuk subjektif, karena dalam pelaksanaannya sering dipengaruhi oleh faktor subjektifitas guru.

Selama ini di IKIP Budi Utomo evaluasi yang dilakukan pada mata kuliah tersebut berupa evaluasi berbasis kertas. Instrumen evaluasi yang diberikan biasanya berupa tes di kelas. Evaluasi berbasis kertas memakan biaya yang tidak sedikit. Implementasi evaluasi berbasis kertas yang manual terkadang rawan terdapat kecurangan, misalnya mahasiswa menyontek teman sebelahnya, mahasiswa membawa contekan sendiri (catatan kecil). Selain itu, tahap pengkoreksian evaluasi berbasis kertas akan memakan waktu yang tidak singkat. Dosen harus mengoreksi satu persatu. Jika jawaban yang dikoreksi banyak dan dosen tidak teliti (human error) akan menimbulkan hasil evaluasi yang tidak akurat, selain itu faktor subyektifitas penilai dengan mahasiswa dapat berpengaruh.

Beberapa kelemahan pada implementasi evaluasi berbasis kertas, peneliti memberikan inovasi pada evaluasi pembelajaran yaitu dengan mengembangkan instrumen evaluasi hasil belajar berbasis mobile online. Mobile learning (m-learning) adalah model pembelajaran yang memanfaatkan TIK(Teknologi Informasi dan Komunikasi). Menurut Tamimudin (2007), Mobile learning (m-learning) merupakan bagian dari electronik learning(e-learning) dan distance learning(d-learning). M-learning merupakan model pembelajaran berbasis mobile(perangkat elektronik smartphone). Pemanfaatan TIK dalam proses pembelajaran dilakukan dalam berbagai bentuk antara lain penyediaan bahan ajar secara online (bahan ajar tersimpan dalam bentuk buku atau artikel di internet), program computer assisted learning, 
bahan alat peraga atau simulasi, pembelajaran Moodle dan Facebook (Darmawan \& Siti, 2014), dan pembelajaran jarak jauh (sekolah terbuka).

Menurut Tasri (2011) banyak lembaga pendidikan memanfaatkan sistem e-learning untuk meningkatkan kemudahan dan fleksibilitas pembelajaran. Beberapa kemudahan tersebut menjadi faktor pendorong mengembangkan mobile untuk diinovasikan dalam pembelajaran. Menggunakan perangkat mobile menjadi solusi atas keterbatasan siswa dalam mengakses sumber materi pembelajaran yang dapat dilakukan dimana saja dan kapan saja. Tingkat penggunaan relatif mudah, harga perangkat semakin terjangkau dibandingkan perangkat komputer personal (Majid, 2012). Inovasi perangkat mobile dalam pendidikan merubah cara belajar peserta didik yang digunakan sebagai media pembelajaran. Dengan memanfaatkan smartphone sebagai media pembelajaran untuk menunjang bahan ajar, tentu akan menciptakan suasana belajar yang lebih komunikatif dan menarik. Hal ini sejalan dengan wacana yang dicanangkan oleh Rektor IKIP Budi Utomo yaitu pembelajaran berbasis paperless (meminimalisir penggunaan kertas).

Pengembangan pemanfaatan TIK selanjutnya digunakan sebagai evaluasi hasil belajar atau yang lebih dikenal CBT (Computer Based Test). Seiring perkembangan teknologi, CBT dapat dikembangkan berbasis Mobile Online. Sistem dalam instrumen evaluasi berbasis mobile online ini mengacu pada model CAT menurut Luecht dan Sireci (2011). Model CAT memuat sejumlah butir soal dengan tingkat kesukaran yang bervariasi dan karakteristik butir soal lainnya. Peserta ujian langsung menghadap komputer dan butir soal yang dapat dikerjakan muncul satu per satu di layar komputer sesuai dengan kemampuan peserta ujian. Dari soal yang tersedia bila peserta ujian tidak dapat menjawab atau salah menjawab pada tingkat tertentu maka ujian berakhir. Berdasarkan soal yang dapat dikerjakan dapat diketahui atau diperoleh tingkat kemampuan peserta ujian dan bila melampui target yang telah ditetapkan maka peserta ujian dinyatakan berhasil dan bila belum peserta ujian dapat mengulang kembali sampai yang bersangkutan dinyatakan lulus.

Evaluasi berbasis mobile online menggunakan perangkat elektronik berupa ponsel berbantuan aplikasi Google Form. Alasan dipilihnya penggunaan ponsel yaitu dengan pertimbangan 90\% setiap mahasiswa IKIP Budi Utomo menggunakan ponsel Android. Di dalam Android sudah include dengan aplikasi Google Form. Adapun beberapa fungsi Google Form untuk dunia pendidikaan menurut Batubara (2016), adalah sebagai berikut: 1) Memberikan tugas latihan/ ulangan online melalui laman website, 2) Mengumpulkan pendapat orang lain melalui laman website, 3) Mengumpulkan berbagai data siswa/ guru melalui 
halaman website, 4) Membuat formulir pendaftaran online untuk sekolah, 5) Membagikan kuesioner kepada orang-orang secara online. Penggunaan Google Form sebagai alat penilaian proses pembelajaran juga mendukung program penghematan kertas sebagagai wujud peduli lingkungan. Selain itu, tenaga dan waktu yang diperlukan guru untuk menyebarkan angket dan mengolah datanya lebih hemat dan mudah.

Evaluasi berbasis mobile setiap soal tes dapat diatur berbatasan waktu dan dapat diacak. Hal ini menjadikan mahasiswa akan fokus pada soal dan tidak ada kesempatan untuk menyontek pada teman lain. Sehingga meminimalisir kecurangan selama evaluasi dilaksanakan. Setelah soal tes selesai dikerjakan maka skor hasil evaluasi akan muncul, hal ini dapat meminimalisir terjadi kesalahan pengkoreksian sehingga hasil pengumuman cepat dan akurat.

Berdasarkan pemaparan diatas, peneliti tertarik untuk mengadakan penelitian pengembangan dengan judul "Pengembangan instrumen evaluasi hasil belajar berbasis mobile online pada mata kuliah belajar dan pembelajaran."

\section{METODE PENELITIAN}

Jenis penelitian yang digunakan adalah penelitian pengembangan. Sugiyono (2012) menjelaskan pengembangan berarti memperdalam dan memperluas pengetahuan, tindakan dan produk yang telah ada. Penelitian pengembangan mengacu pada model pengembangan 4D. Model pengembangan 4D terdiri dari tahap define, design, develop, dan disseminate (Thiagarajan, Semmel, \& Semmel, 1974).

Langkah-langkah pelaksanaannya cukup sederhana, sistematis, dan mudah dipahami.

\section{Tahap Define (Pendefinisian)}

Tujuan dari tahap ini adalah untuk menetapkan dan menentukan kebutuhan instruksional. Selama analisis, ditentukan tujuan untuk bahan instruksional. Ada lima langkah yang harus ditempuh pada tahap define yaitu analisis awal-akhir, analisis evaluasi peserta didik, analisis tugas, dan analisis konsep.

\section{Tahap Design (Desain)}

Tujuan dari tahap ini adalah untuk mendesain prototipe instrumen evaluasi hasil belajar berupa kuis online berbasis mobile berbantuan Google Form. Langkah ini dapat ditempuh setelah penentuan tujuan atau sasaran instrumen. Pemilihan media dan format untuk bahan dan produksi sebuah versi awal kuis online merupakan aspek utama dari tahap desain (Thiagarajan et al., 1974). Keempat langkah pada tahap desain yaitu menyusun kriteria-kriteria yang akan 
dijadikan dasar dalam penyusunan prototipe. Langkah ini mengubah tujuan-tujuan yang dihasilkan dari tahap define; pemilihan format kuis online; dan penyusunan desain awal.

\section{Tahap Develop (Pengembangan)}

Thiagarajan, et al (1974) menyatakan bahwa tujuan dari tahap ini adalah memodifikasi prototype instrumen evaluasi kuis online. Hasil pengembangan yang berupa desain awal harus dimodifikasi sebelum dinyatakan menjadi desain final yang efektif. Pada tahap pengembangan, umpan balik didapatkan melalui evaluasi formatif dan instrumen yang harus direvisi. Langkahlangkah pada tahap Develop yaitu.

a. Validasi ahli. Langkah ini merupakan teknik untuk menghasilkan saran dengan tujuan meningkatkan kualitas instrumen evaluasi kuis online. Sejumlah ahli akan mengevaluasi instrumen evaluasi kuis online dan selanjutnya dilakukan revisi.

b. Tes pengembangan. Langkah ini mencakup mengujicobakan instrumen evaluasi kuis online ke peserta didik untuk mengetahui letak bagian yang harus direvisi. instrumen evaluasi kuis online dimodifikasi berdasarkan respon, reaksi, dan komentar dari peserta uji coba.

\section{Tahap Disseminate (Penyebarluasan)}

Instrumen evaluasi kuis online mencapai tahap produksi akhir ketika tes pengembangan menghasilkan hasil yang konsisten dan ahli instrumen evaluasi kuis online memberikan komentar yang positif. Sebelum pengemasan akhir, dilakukan uji formatif untuk menentukan efektifitas produk. Langkah pengemasan akhir, difusi, dan adaptasi sangat penting, meskipun terkadang sering diabaikan. Produser dan distributor harus dipilih untuk mengemas instrumen evaluasi kuis online ke dalam bentuk yang sesuai dan dapat diterima oleh kalangan yang lebih luas.

Instrumen utama dalam penelitian adalah peneliti yang merencanakan, melakukan observasi, mengumpulkan data, mengembangkan produk dan melaporkan hasil penelitian. Instrumen pendukung penelitian ini adalah lembar validasi ahli, soal tes dan angket respon mahasiswa.

1. Lembar validasi ahli

Validasi dilakukan pada validator ahli media, validator ahli materi dan praktisi. Lembar validasi ahli memuat penilaian dari ahli tentang kevalidan produk yang dikembangkan. Selain itu lembar validasi ahli juga memuat saran dan komentar ahli sebagai bahan revisi produk yang dikembangkan.

2. Soal tes 
Tes digunakan sebagai instrumen evaluasi hasil belajar. Tes digunakan untuk mengetahui keefektifan instrumen terhadap konsep Belajar dan Pembelajaran. Tes diberikan setelah dilaksanakaan uji coba terhadap produk pengembangan.

3. Angket respon mahasiswa

Angket respon digunakan untuk mengetahui keefektifan instrumen evaluasi ditinjau dari respon mahasiswa terhadap konsep Belajar dan pembelajaran. Selanjutnya hasil dari angket respon mahasiswa digunakan sebagai bahan revisi produk yang dikembangkan.

Data yang digunakan dalam penelitian diperoleh dengan cara memberikan lembar validasi, angket respon mahasiswa dan tes. Pengumpulan data dilakukan untuk mengembangkan dan menghasilkan perangkat.

Tabel 1. Data, Prosedur Pengumpulan Data dan Instrumen Penelitian

\begin{tabular}{lll}
\hline \multicolumn{1}{c}{ Data } & \multicolumn{1}{c}{$\begin{array}{c}\text { Prosedur } \\
\text { Pengumpulan Data }\end{array}$} & \multicolumn{1}{c}{ Instrumen } \\
\hline Kevalidan produk & Validasi ahli & Lembar validasi ahli \\
Kepraktisan & Pemberian angket repon mahasiswa & Angket respon mahasiswa \\
Keefektifan produk & Pemberian tes & Soal tes \\
\hline
\end{tabular}

1. Analisis hasil validasi ahli

Lembar validasi ahli memuat penilaian, saran dan komentar terhadap produk yang dikembangkan. Penilaian menggunakan 4 skala, yaitu 1 (kurang baik), 2 (cukup baik), 3 (baik), dan 4 (sangat baik). Rata-rata skor penilaian dari validasi ahli menjadi acuan untuk mengetahui kevalidan produk yang dikembangkan. Perhitungan rata-rata skor penilaian dari ahli dapat dilakukan sebagai berikut.

$$
X=\frac{\sum x}{n}
$$

$X$ merupakan rata-rata skor penilaian ahli, $\sum x$ merupakan jumlah skor penilaian ahli, dan $n$ jumlah indikator penilaian dalam lembar validasi. Kriteria penilaian dari ahli disajikan dalam Tabel 2.

Tabel 2. Kriteria Penilaian Validator Ahli

\begin{tabular}{cc}
\hline Skor Rata-Rata Penilaian & Kriteria Penilaian \\
\hline $3 \leq X \leq 4$ & Valid \\
$2 \leq X<3$ & Cukup valid \\
$1 \leq X<2$ & Kurang valid \\
$0 \leq X<1$ & Tidak valid \\
\hline
\end{tabular}

Prima, Vol. 4, No. 1, Januari 2020, 46-63. 
2. Hasil angket respon mahasiswa

Angket respon mahasiswa digunakan untuk mengetahui kepraktisan produk yang dikembangkan dan diujicobakan. Produk berupa perangkat pembelajaran dikatakan efektif jika skor rata-rata hasil angket respon mahasiswa termasuk dalam kriteria baik. Penilaian menggunakan 4 skala, yaitu 1 (kurang setuju), 2 (cukup setuju), 3 (setuju), dan 4 (sangat setuju). Perhitungan rata-rata skor angket respon mahasiswa dapat dilakukan sebagai berikut.

$$
X=\frac{\sum x}{n}
$$

$X$ merupakan rata-rata skor angket respon mahasiswa, $\sum x$ merupakan jumlah skor penilaian respon mahasiswa, dan $n$ jumlah indikator penilaian dalam angket respon mahasiswa. Kriteria penilaian disajikan dalam Tabel 3.

Tabel 3. Kriteria Penilaian Angket Respon Mahasiswa

\begin{tabular}{cc}
\hline Skor Rata-Rata Penilaian & Kriteria Penilaian \\
\hline $3 \leq X \leq 4$ & Sangat baik \\
$2 \leq X<3$ & Baik \\
$1 \leq X<2$ & Cukup baik \\
$0 \leq X<1$ & Kurang baik \\
\hline
\end{tabular}

3. Analisis hasil tes

Hasil tes digunakan untuk mengetahui keefektifan produk yang dikembangkan dan diujicobakan. Produk berupa perangkat pembelajaran dikatakan efektif jika skor rata-rata hasil tes mahasiswa termasuk dalam kriteria baik. Kriteria penilaian hasil tes disajikan dalam Tabel 4.

Tabel 4. Kriteria Penilaian Hasil Tes

\begin{tabular}{cc}
\hline Skor Rata-Rata Hasil Tes & Kriteria Penilaian \\
\hline $90 \leq X \leq 100$ & Sangat baik \\
$80 \leq X<90$ & Baik \\
$70 \leq X<80$ & Cukup baik \\
$X<70$ & Kurang baik \\
\hline
\end{tabular}

Berdasarkan hasil analisis tersebut dapat disimpulkan kevalidan, kepraktisan dan keefektifan media yang mengacu pada Tabel 5 berikut.

Tabel 5. Kriteria kelayakan media

\begin{tabular}{ll}
\hline \multicolumn{1}{c}{ Aspek } & \multicolumn{1}{c}{ Kriteria } \\
\hline Kevalidan & Rata-rata hasil validasi dari ahli materi minimal mencapai kriteria valid \\
Kepraktisan & $\begin{array}{l}\text { Rata-rata penilaian dari angket respon mahasiswa minimal mencapai } \\
\text { kriteria baik }\end{array}$ \\
Keefektifan & Rata-rata hasil tes mahasiswa minimal mencapai kriteria baik \\
\hline
\end{tabular}




\section{HASIL DAN PEMBAHASAN}

Adapun hasil dari penelitian dijabarkan sebagai berikut:

\section{Define (Pendefinisian)}

Tahap define merupakan tahap awal dalam pengembangan instrumen evaluasi hasil belajar berupa kuis online. Pada tahap define dilakukan serangkaian kegiatan yaitu analisis tujuan awal, analisis peserta didik, analisis tugas, analisis konsep dan perumusan tujuan pembelajaran. Peneliti sebelumnya melalukan observasi dan wawancara kepada mahasiswa pada kegiatan pembelajaran mata kuliah belajar dan pembelajaran prodi Pendidikan Matematika. Melalui observasi dan wawancara diperoleh fakta bahwa kegiatan evaluasi dilakukan dengan berbasis kertas dan belum pernah dilakukan evaluasi hasil belajar berupa kuis online.

Melalui evaluasi berbasis kertas, dosen menyiapkan soal yang dicetak pada kertas dan lembar jawaban kosong yang disebar sejumlah peserta evaluasi. Evaluasi berbasis kertas memakan biaya yang tidak sedikit. Impelementasi evaluasi berbasis kertas yang manual terkadang rawan terdapat kecurangan, misalnya mahasiswa menyontek teman sebelahnya, mahasiswa membawa contekan sendiri (catatan kecil) karena batasan waktu setiap soal tidak ditentukan sehingga mahasiswa kurang fokus. Selain itu, tahap pengkoreksian evaluasi berbasis kertas akan memakan waktu yang tidak singkat. Dosen harus mengoreksi satu persatu. Jika jawaban yang dikoreksi banyak dan dosen tidak teliti (human error) akan menimbulkan hasil evaluasi yang tidak akurat, selain itu faktor subyektifitas penilai dengan mahasiswa dapat berpengaruh.

Evaluasi berbasis mobile online menggunakan perangkat elektronik berupa ponsel. Alasan dipilihnya penggunaan ponsel yaitu dengan pertimbangan 99\% setiap mahasiswa IKIP Budi Utomo menggunakan ponsel Android, tersedianya koneksi internet melalui wifi yang merupakan fasilitas kampus yang lancar. Salah satu software yang mudah diakses, gratis digunakan, sederhana dalam pengoperasiannya dan cukup baik untuk dikembangkan sebagai alat evaluasi pembelajaran adalah Google Form. Google Form merupakan salah satu komponen layanan Google Docs. Google Docs merupakan bagian dari layanan Android.

Analisis konsep dan tugas adalah materi mata kuliah Belajar dan Pembelajaran. Pembelajaran. Belajar dan Pembelajaran merupakan salah satu mata kuliah institusi yang wajib ditempuh mahasiswa Pendidikan Matematika IKIP Budi Utomo Malang. Standar kompetensi dalam mata kuliah ini adalah agar mahasiswadapat menerapkan konsep dasar belajar pembelajaran. Adapun manfaatnya diantaranya 1) Mahasiswa dapat memahami konsep dasar 
dalam belajar dan pembelajaran. 2) Mahasiswa mampu menerapkan konsep dasar belajar dan pembelajaran di sekolah. Mata kuliah ini meliputi kajian hakikat belajar danpembelajaran, prinsip dan implikasi belajar pembelajaran, teori belajar dan implementasi dalam proses pembelajaran, gaya dan masalah-masalah belajar, siklus belajar, komunikasi pembelajaran, metode pembelajaran inovatif, dan evaluasi pembelajaran.

Software pendukung yang dibutuhkan adalah memanfaatkan Google Form sebagai penilaian berbasis mobile online. Google Form berbatasan waktu dan dapat diacak. Hal ini menjadikan mahasiswa akan fokus pada menjawab soal karena antara peserta satu dengan yang lainnya soal yang ditampilkan tidak sama dan tidak ada kesempatan untuk menyontek pada teman lain. Sehingga meminimalisir kecurangan selama evaluasi dilaksanakan. Setelah soal tes selesai dikerjakan maka skor hasil evaluasi akan muncul, hal ini dapat meminimalisir terjadi kesalahan pengkoreksian sehingga hasil pengumuman cepat dan akurat.

\section{Design (Perancangan)}

Pada tahap ini dilakukan perancangan instrumen evaluasi yang dikembangkan. Langkahlangkah tahap perancangan ini adalah menyusun tes dan kunci jawaban, membuat email, memilih desain template yg sesuai, membuat instrumen evaluasi online dengan bantuan Google Form, mengecek pratinjau, memberikan pengaya, memperpendek link dengan bantuan bit.ly, mengelola tanggapan.

Langkah awal yang dilakukan pada tahap design adalah menyusun tes dan kunci jawaban. Tes yang digunakan merupakan tes UAS (Ujian Akhir Semester). Materi yang diujikan merupakan materi matakuliah Belajar dan Pembelajaran selama satu semester. Tes yang diujikan berjumlah 50 butir soal. Butir soal yang digunakan pada tes ini merupakan pertanyaan tertutup dimana sistem evaluasi sudah menyediakan jawaban. Tampilan evaluasi online ini terdiri dari 4 bagian. Bagian pertama berisi input data diri siswa. Bagian kedua berisi butir soal jenis pertanyaan pilihan ganda sejumlah 30 soal. Bagian ketiga berisi butir soal jenis jawaban benar salah yang terdiri dari 10 soal. Bagian keempat berisi butir soal jenis isian singkat yang sejumlah 10 soal. Skor total perolehan mahasiswa adalah 100 point, sedangkan setiap butir soal apabila menjawab benar mendapat 2 point.

Langkah selanjutnya adalah membuat akun Google. Membuat akun Google syaratnya adalah dengan memasukkan alamat email (elektronik-mail) pada Gmail. Gmail adalah layanan surat elektronik milik Google. Google Form tidak bisa digunakan pada layanan surat elektronik lain (misalnya Yahoo), karena Google Form adalah fasilitas yang dimiliki oleh Google, jadi jika ingin menggunakan Google Form maka wajib mempunyai akun Google. 
Setelah memiliki akun Google, kita mendapatkan layanan aplikasi Google Drive, Google Maps, Google Mail, Youtube. Google Drive adalah layanan penyimpanan daring milik Google. Layanan Google Drive merupakan ekstensi dari Google Docs dan akan mengganti URL docs.google.com. Google Forms adalah aplikasi administrasi survei yang termasuk dalam suite kantor Google Drive bersama dengan Google Documents, Google Sheets, dan Google Slides. Formulir menampilkan semua fitur kolaborasi dan berbagi yang ditemukan di Documents, Spreadsheet, dan Slide.

Google Form merupakan salah satu komponen layanan Google Docs. Aplikasi ini sangat cocok untuk mahasiswa, guru, dosen, pegawai kantor dan professional yang senang membuat quiz, form, dan survey online. Fitur dari Google Form dapat di bagi ke orang-orang secara terbuka atau khusus kepadapemilik akun Google dengan pilihan aksesibilitas, seperti: read only (hanya dapat membaca) atau editable (dapat mengedit dokumen). Selain itu, Google docs juga dapat menjadi alternatif bagi orang-orang yang tidak memiliki dana untuk membeli aplikasi berbayar untuk menggunakan program gratisan dibandingkan membajak program berbayar seperti Microsoft Office, karena kita tahu bahwa membajak program itu adalah tidak baik.

Adapun beberapa fungsi Google Form untuk dunia pendidikan menurut Batubara (2016), adalah sebagai berikut: 1) Memberikan tugas latihan/ ulangan online melalui laman website, 2) Mengumpulkan pendapat orang lain melalui laman website, 3) Mengumpulkan berbagai data siswa/ guru melalui halaman website, 4) Membuat formulir pendaftaran online untuk sekolah, 5) Membagikan kuesioner kepada orang-orang secara online.

Penggunaan Google Form sebagai alat penilaian proses pembelajaran juga mendukung program penghematan kertas sebagagai wujud peduli lingkungan. Selain itu, tenaga dan waktu yang diperlukan guru untuk menyebarkan angket dan mengolah datanya lebih hemat dan mudah.

Layanan Google Form atau disebut Google formulir adalah aplikasi yang berguna untuk membantu merencanakan acara, mengirim survei, memberikan siswa atau orang lain kuis, atau mengumpulkan informasi yang mudah dengan cara yang efisien. Google Form dapat diakses menggunakan PC Desktop dan mobile (smartphone) dengan sistem operasi Android. Berdasarkan latar belakang masalah, mahasiswa di lingkungan prodi Matematika banyak yang memiliki smartphone maka agar lebih efisien proses penyelesaian kuis menggunakan smartphone.

Rancangan tes yang diujikan berjumlah 50 butir soal terdiri dari 30 butir soal berjenis pilihan ganda, 10 butir soal berjenis benar salah, dan 10 butir soal berjenis isian singkat. Butir

Prima, Vol. 4, No. 1, Januari 2020, 46-63. 
soal yang diujikan merupakan pertanyaan tertutup. Materi yang diujikan adalah mata kuliah Belajar dan Pembelajaran. Butir soal yang diujikan ditampilkan secara acak. Batasan waktu yang diberikan adalah 90 menit.

Rancangan awal evaluasi online terdiri dari 4 bagian, yaitu:

Bagian pertama meminta user untuk menginput data diri. Data diri terdiri dari Nama Lengkap, NPM, dan Offering. Input data bersifat wajib diisi. Jika tidak diisi maka user tidak dapat melanjutkan ke bagian berikutnya. Data diri bertujuan untuk memberikan identitas mahasiswa. Tampilan bagian input data diri ada pada Gambar 1.

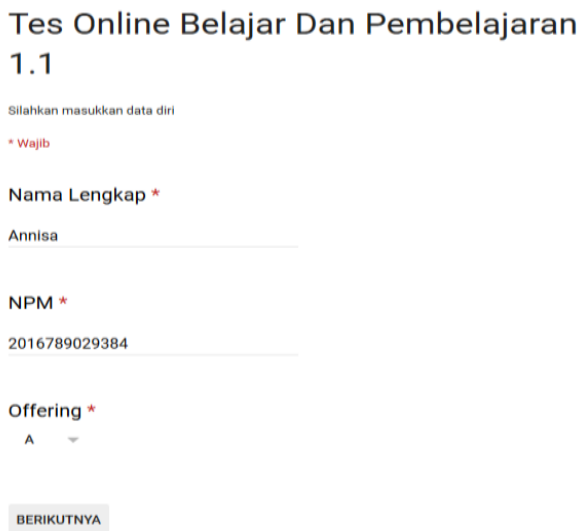

Gambar 1. Tampilan Input Data Diri User

Bagian kedua berisi butir soal pilihan ganda. Butir soal pilihan ganda berjumlah 30 butir soal. Butir soal pilihan ganda hanya memiliki 1 jawaban benar. Setiap butir memiliki 2 point jika menjawab benar. Butir soal dalam bagian ini wajib diisi jawaban. Jika salah satu butir soal tidak diisi jawaban maka user tidak dapat melanjutkan pada bagian selanjutnya. Tombol kembali artinya kembali kepada pertanyaan pada slide sebelumnya. Tombol berikutnya artinya user akan menuju pertanyaan selanjutnya Tampilan bagian soal pilihan ganda ada pada Gambar 2.

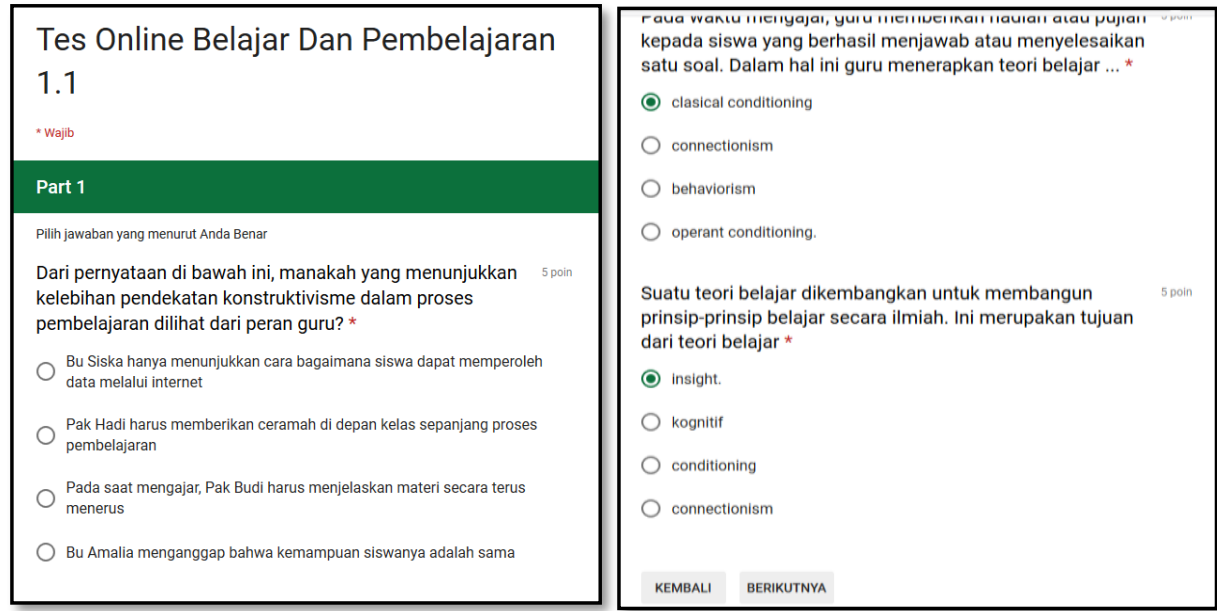

Gambar 2. Tampilan Bagian Kedua berisi soal pilihan ganda 
Bagian ketiga berisi butir soal jenis benar salah. User diminta memilih jawaban yang benar. Butir soal benar salah memiliki jawaban lebih dari satu. Butir soal benar salah berjumlah 10 butir soal. Tampilan bagian soal pilihan ganda ada pada Gambar 3.

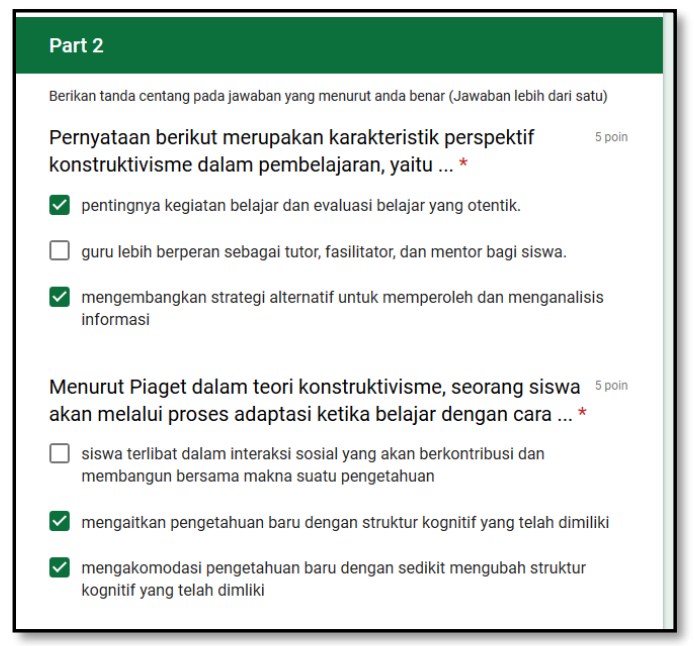

\section{Gambar 3. Tampilan Bagian Ketiga berisi soal benar salah}

Bagian keempat berisi butir soal dengan jenis isian singkat. Butir soal jenis isian singkat berjumlah 10 soal. Jika jawaban benar memiliki 2 point. Tampilan bagian soal benar salah ada pada Gambar 4.

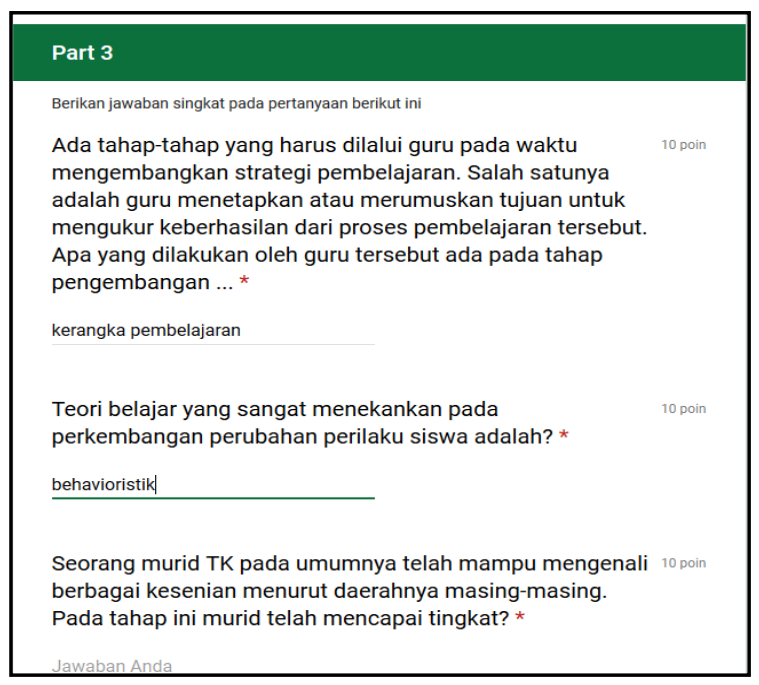

\section{Gambar 4. Tampilan Bagian Soal isian singkat}

Butir soal dalam bagian ini wajib diisi jawaban. Jika salah satu butir soal tidak diisi jawaban maka user tidak dapat melanjutkan pada bagian selanjutnya. Pertanyaan yang tidak diisi jawaban akan mendapatkan peringatan seperti pada Gambar 5. 


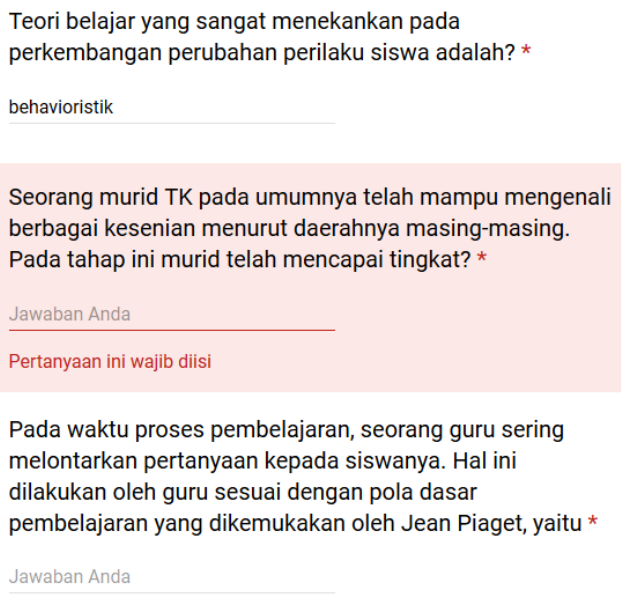

\section{Gambar 5. Peringatan jawaban harus diisi}

Proses pengerjaan tes ini berbatasan waktu. Jika dalam durasi waktu yang telah ditentukan sudah habis, maka tes tidak dapat diakses dan jawaban tidak dapat dinilai oleh sistem. Selanjutnya, setelah peserta didik menyelesaikan butir soal pada akhir pertanyaan akan diminta terdapat tombol kembali dan dikirim. Tombol kembali artinya user kembali kepada pertanyaan sebelumnya. Tombol dikirim artinya user sudah merasa jawabannya tepat dan mengirim kepada sistem untuk dinilai. Tampilan bagian pertanyaan terakhir seperti pada Gambar 6.

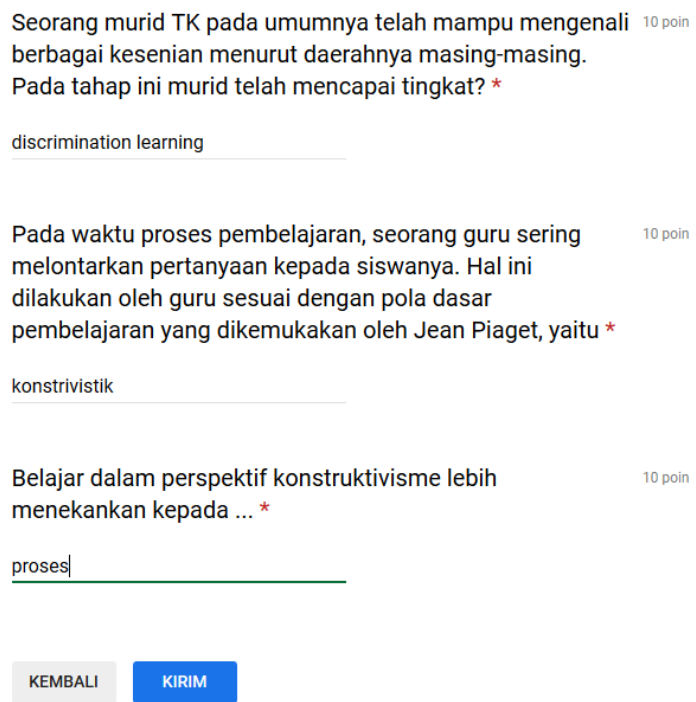

Gambar 6. Tampilan Bagian Terakhir

Setelah user (peserta didik) mengirim jawaban, maka sistem akan menilai secara otomatis. Proses penilaian akan ditampilkan seperti pada Gambar 7. Point:60/100 artinya user mendapatkan nilai point 60 dari point total 100 . 


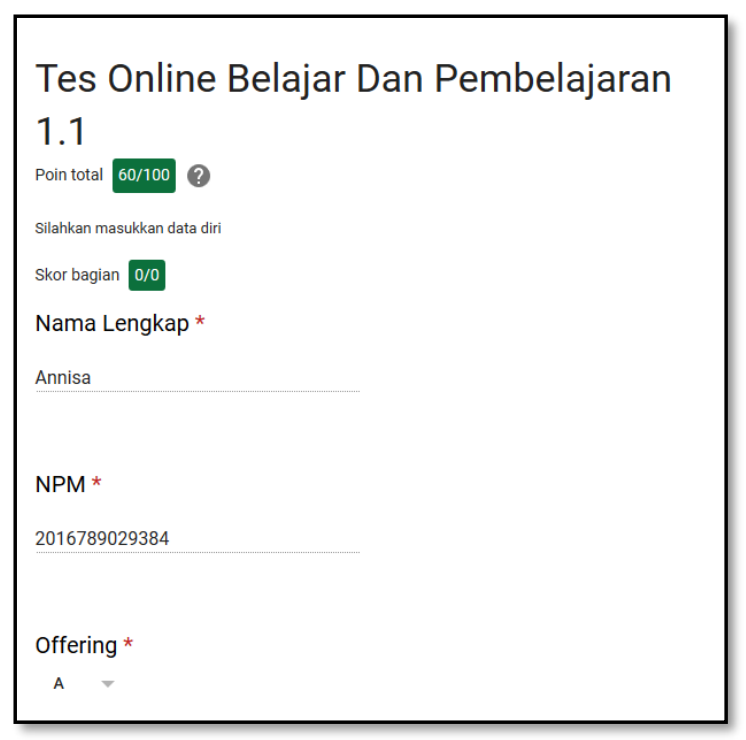

Gambar 7. Tampilan Hasil Penilaian

Hasil penilaian butir soal yang sudah dikerjakan user akan dinilai benar dan salah. Setiap soal benar dan salah akan diberikan masukan dan pembahasan. Jawaban benar dan salah akan ditampilkan seperti Gambar 8.
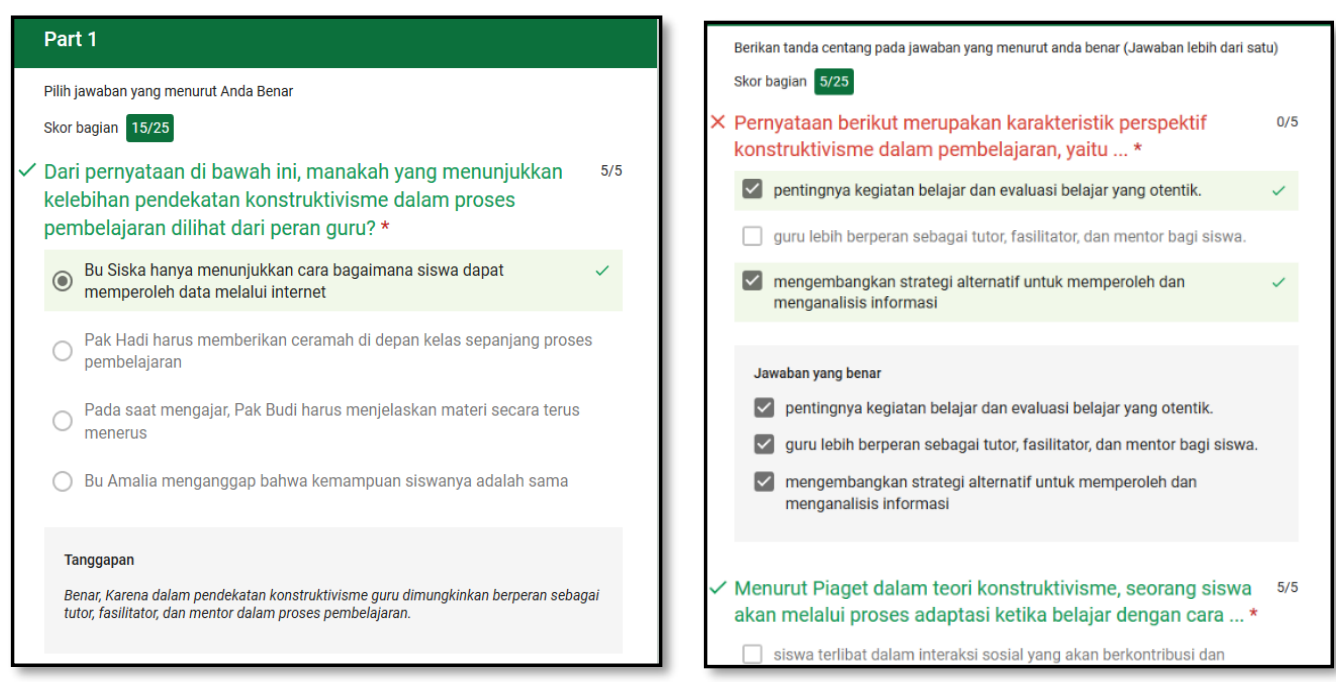

Gambar 8. Tanggapan Masukan Jawaban yang Benar

\section{Develop (Pengembangan)}

Pada tahap develop dilakukan tahap pengubahan rancangan dasar instrumen evaluasi online hingga mencapai versi akhir untuk digunakan. Pada tahap develop, instrumen yang sudah didesain divalidasi oleh ahli media. Validator ahli media merupakan dosen prodi Pendidikan Matematika dengan keahlian bidang komputasi. Secara terperinci, penilaian tingkat kevalidan dipengaruhi dari 3 indikator yaitu aspek fungsionalitas, Reliabilitas, dan Usabilitas. Hasil validasi ahli media diperoleh rata-rata 3,66 yang berada pada kriteria Sangat Valid. Selain itu, terdapat saran dan kritik dari validator ahli media bahwa saran pertama petunjuk soal perlu 
direvisi agar kata-kata tidak ambigu. Saran pertama direvisi seperti pada Gambar 9. sesuai dengan saran dari validator, kalimat petunjuk "pilih jawaban yang menurut Anda benar" direvisi menjadi "Jenis soal pilihan ganda, silahkan pilih satu jawaban yang menurut Anda benar".
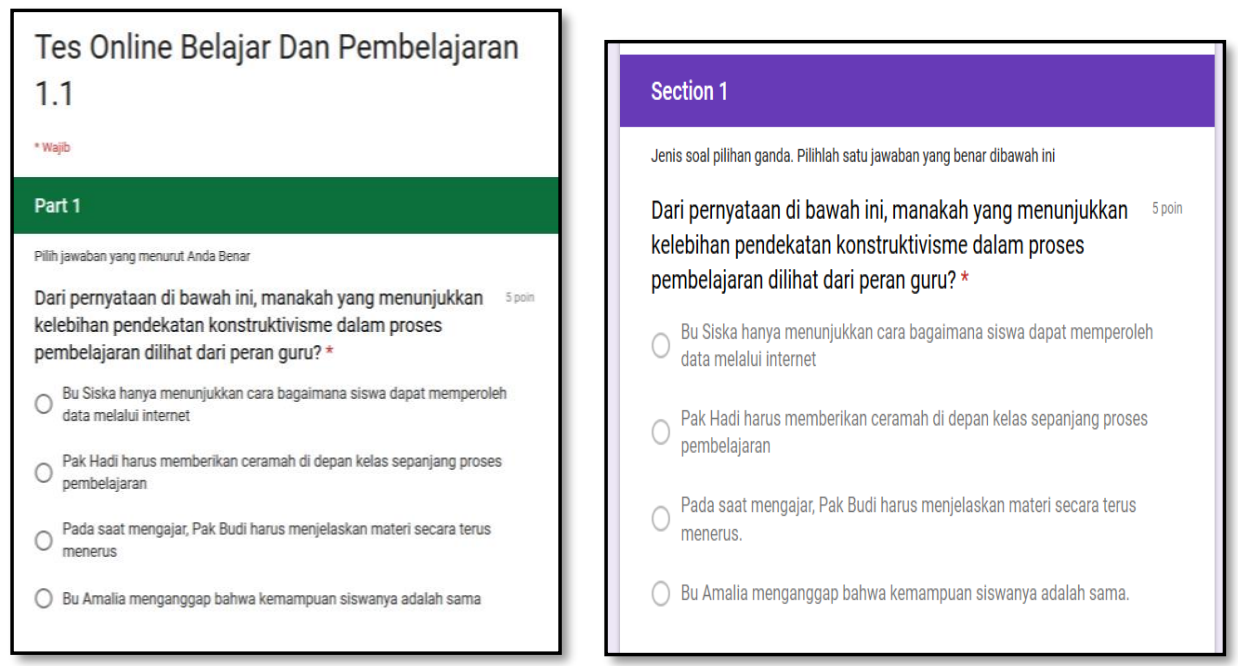

Gambar 9. Sebelum dan sesudah revisi

Saran lain adalah link website menuju Google form diperpendek saja, supaya tidak membingungkan users. Untuk membuka halaman tes online, dibutuhkan sebuah alamat. Alamat dari Google Form awalnya sangat panjang, oleh karena itu untuk memudahkan users menuju alamat tersebut ada baiknya alamat halaman tersebut diperpendek. Memperpendek alamat halaman web dapat menggunakan bantuan layanan bit.ly. alamat awal halaman tes online

adalah https://docs.google.com/forms/d/e/1FAIpQLSegXhM6MRfTMBDNj6IAVXraYTbifTKWM10ZQMjAn7YiwwK-w/viewscore?viewscore=AE0zAgCmJcircay6IlQh6tRLMUDPDB8BeVgz0gFN8N0HKN8nKI6QQi9cv4dZ3xcqHLtoQk dan diatur untuk diperpendek menjadi http://bit.ly/tesonlinebdp.

Pada tahap develop juga dilakukan ujicoba untuk mnegetahui kepraktisan media melalui pemberian angket respon user(mahasiswa) dan keefektifan media memlalui pemberian soal tes. Secara terperinci aspek kepraktisan ini ditinjau dari empat indikator, yaitu aspek operability, learnability, undersability, dan attractivenes. Keempat indikator dalam pengujian media tersebut merupakan aspek standar perangkat lunak ISO 9126. Rata-rata penilaian kepraktisan dari keempat indikator adalah 3.02 (kriteria baik). Tes diberikan setelah mahasiswa menggunakan instrumen evaluasi hasil belajar. Rata-rata hasil tes mahasiswa adalah 80,67 yang berada pada kriteria baik. Berdasarkan angket respon dan tes mahasiswa maka instrumen evaluasi berupa kuis online dapat dikatakan praktis dan efektif. 
Berdasarkan wawancara dengan Dosen pada pembelajaran yang menerapkan evaluasi online didapatkan kesimpulan bahwa pelaksanaan evaluasi online menghemat biaya karena tidak menggunakan kertas (paperless), pelaksanaan evaluasi memudahkan pengkoreksian karena setelah mahasiswa mengerjakan nilai otomatis sudah ditampilkan sehingga menghemat waktu dan hasil penilaian transparan, pelaksanaan evaluasi online membuat mahasiswa fokus mengerjakan karena berbatasan waktu dan formulir tidak bisa diakses jika durasi waktu yang diberikan sudah habis.

Berdasarkan tahap penelitian yang telah dilakukan di dapat hasil sebagai berikut.

a. Instrumen evaluasi hasil belajar berupa tes online yang dikembangkan memenuhi aspek kevalidan berdasarkan lembar validasi penilaian ahli media berada pada kriteria valid dengan rata-rata 3,66.

b. Instrumen evaluasi hasil belajar berupa tes online yang dikembangkan memenuhi aspek kepraktisan berdasarkan angket respon mahasiswa berada pada kriteria baik dengan rata-rata 3,02.

c. Instrumen evaluasi hasil belajar berupa tes online yang dikembangkan memenuhi aspek keefektifan berdasarkan hasil tes mahasiswa berada pada kriteria baik dengan rata-rata 80,67 .

\section{Disseminate (Penyebarluasan)}

Tahap Disseminate dalam penelitian ini terbatas penggunaanya pada Prodi Matematika IKIP Budi Utomo Malang. Penyebarluasan evaluasi online melalui alamat sebuah wesite. Untuk membuka halaman tes online, dibutuhkan sebuah alamat. Alamat dari Google Form awalnya sangat panjang, oleh karena itu untuk memudahkan users menuju alamat tersebut ada baiknya alamat halaman tersebut diperpendek. Memperpendek alamat halaman web dapat menggunakan bantuan layanan bit.ly. alamat awal halaman tes online adalah https://docs.google.com/forms/d/e/1FAIpQLSegXhM6MRfTMBDNj6IAVXraYTbifTKWM10ZQMjAn7YiwwK-w/viewscore?viewscore=AE0zAgCmJcircay6IlQh6tRLMUDPDB8BeVgz0gFN8N0HKN8nKI6QQi9cv4dZ3xcqHLtoQk dan diatur untuk diperpendek menjadi http://bit.ly/tesonlinebdp.

\section{SIMPULAN DAN SARAN}

Dari perhitungan analisis data yang didapat dari perhitungan data, instrumen yang dikembangkan layak digunakan untuk evaluasi hasil tes mata kuliah Belajar dan Pembelajaran dan bisa di aplikasikan dalam mata kuliah lain.

Prima, Vol. 4, No. 1, Januari 2020, 46-63. 


\section{DAFTAR PUSTAKA}

Arikunto, S. (2012). Dasar-dasar Evaluasi Pendidikan. Jakarta: Bumi Aksara.

Aunurrahman. (2014). Belajar dan Pembelajaran. Bandung: Alfabeta.

Batubara, H. H. (2016). Penggunaan Google Form Sebagai Alat Penilaian Kinerja Dosen di Prodi PGMI UNISKA Muhammad Arsyad AlBanjari. Al-Bidayah: Jurnal Pendidikan Dasar Islam, 8(1), 39-50. Retrieved from http://jurnal.albidayah.id/index.php/home/article/view/91

Budiman, A., \& Jailani, J. (2014). Pengembangan Instrumen Asesmen Higher Order Thinking Skill (HOTS) pada Mata Pelajaran Matematika SMP Kelas VIII Semester I. Jurnal Riset $\begin{array}{llll}\text { Pendidikan } \quad \text { Matematika, } & \text { 1(2). } & \text { Retrieved }\end{array}$ https://journal.uny.ac.id/index.php/jrpm/article/view/2671

Darmawan, D., \& Siti, H. D. (2014). Pengembangan E-Learning Berbasis Mooddle dan Facebook pada Mata Pelajaran TIK. Jurnal Teknodik, 18(3), 227-240. Retrieved from http://118.98.227.127/index.php/jurnalteknodik/article/view/129

Luecht, R. M., \& Sireci, S. G. (2011). A Review of Models for Computer-Based Testing. Retrieved from https://eric.ed.gov/?id=ED562580

Majid, A. (2012). Mobile Learning. Bandung. Retrieved from https://www.google.co.id/url?sa=t\&rct=j\&q=\&esrc=s\&source=web\&cd=2\&cad=rja\&u act=8\&ved=2ahUKEwik3fTNya3nAhUSfisKHcHLCmEQFjABegQIBRAB\&url=http

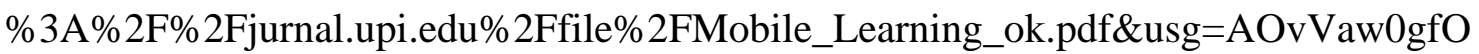
oQoxiKkeSU739sgzWJ

Sugiyono. (2012). Metode Penelitian Kuantitatif, Kualitatif dan R\&D. Bandung: Alfabeta. Sukardi. (2012). Evaluasi Pendidikan Prinsip dan Operassionalnya. Jakarta: Bumi Aksara. Tamimudin, M. (2007). Mengenal Mobile Learning (M-Learning). Limas 8.

Tasri, L. (2011). Pengembangan Bahan Ajar Berbasis Web. Jurnal Medtek, 3(2).

Thiagarajan, S., Semmel, D., \& Semmel, M. (1974). Instructional Development for Training Teachers of Exceptional Children: A Sourcebook. Retrieved from https://eric.ed.gov/?id=ED090725

Wragg, E. C. (1994). Classroom Teaching Skills. Nicholas Publishing Company. Zamzania, A. W. H., \& Aristia, R. (2018). Jenis-jenis Instrumen dalam Evaluasi Pembelajaran. Sidoarjo. Retrieved from http://eprints.umsida.ac.id/4050/ 